\title{
on_education
}

\section{Pedagogy of Description Projective Reading and the Ethics of Interpretation}

\author{
Kinohi Nishikawa (Princeton University)
}

\begin{abstract}
:
This essay limns critique's use of selective or even misleading description to advance ideological commitments, often without drawing explicit attention to those commitments. It posits that this style is especially attractive to identity-based modes of critique that, rather than take an oppositional approach to reading (e.g., reading "against the grain"), enforce a self-identity between the critic and her object. Against this trend, the essay advocates a pedagogy of description that hones the ethics of interpretation at the point of writing about an object's alterity. It focuses on a graduate seminar experience of teaching ekphrasis first through an assigned reading and then through a writing exercise completed in an actual museum space. Students' frustration with a critic's description of certain art works became an opportunity to reflect on their own commitment to writing about objects with care. Building out from that experience, the essay shows how ethics animates post-critique's embrace of wonder and surprise - in teaching as much as in writing.
\end{abstract}

Keywords:

ekphrasis; ethics; description; interpretation; pedagogy

A graduate seminar I taught in fall 2019 surveyed the legacy of the Black Arts movement in aesthetic theory and cultural criticism over the past fifty years. Bookended by Amiri Baraka's Blues People (1963) and Saidiya Hartman's Wayward Lives, Beautiful Experiments (2019), we considered how Black Arts critics and their academic descendants in Black Studies and black feminism write about the arts as a cross-disciplinary, community-oriented enterprise. Since the seminar was organized as an intellectual genealogy, my pedagogy started off emphasizing the way critics in the 1960s and 1970s had established precedents for contemporary theoretical trends. While graduate students often fetishize writing that labels itself theory, few realize that a lot of such writing rehearses or repackages older ideas, including those pitched to a general audience, as Black Arts critics had. But this pedagogical aim soon encountered its own blind spot when students, energized by the earlier material, began to interrogate the practices of contemporary criticism. If some of these ideas have been in circulation for a while, what, exactly, was self-styled theory claiming to do for the academy?

The question came to inform our proceedings by the third meeting. The readings assigned for that discussion were Black Arts essays by Baraka, Larry Neal, Carolyn M. Rodgers, and Sonia Sanchez, among others, and a 2007 essay by Fred Moten, a Black Studies scholar who situates himself as continuing in the tradition of Black Arts. Moten's essay,
"Taste Dissonance Flavor Escape: Preface for a Solo by Miles Davis”, was published in Women and Performance, a distinguished journal of feminist performance studies. The basic method of the essay is to take seemingly abject or compromised positions and interpret them as always already resistant to the forces that would make them so. From this method, Moten extrapolates a theory of "(black) performance as the irruption of the thing through the resistance of the object” (Moten, 2007, p. 218). My students were able to draw a connection between Moten's theory and the veneration of avant-garde jazz in Black Arts criticism, and they could see Baraka's influence in the poetic license Moten took in his critical prose. But discussion hit a snag when we turned to one of Moten's examples of such resistance of the object: a sepia-toned photograph of a nude black girl. The image is reproduced in Moten's essay.

The picture had been taken by white photographer Thomas Eakins (or one of his associates) in his Philadelphia studio in 1882. Completely bare, the girl is shown reclining on a couch, facing the camera, with her right hand tucked under her chin, her left arm draped down along her torso, and her left hand cupped under her buttock. Her hair looks unkempt. Her eyes stare straight into the lens. Her body is as close to the back of the couch as it can go. The floral print of the couch's upholstery is bathed in the light coming from the window or from the camera apparatus itself. I choose my 
words carefully here so as not to reactivate the essential pornography of the scene through ekphrasis.

The same cannot be said for Moten, whose prose, the students were quick to point out, problematically locates resistance in this objectified figure. Take this passage, for example:

The black apparatus, black performance, the thing's interruption of the object in resistance, blackness-asfugitivity, the teleological principle in suspense, the broken breaking bridge and broken circle, cuts the revolt become law, lies before the law, not as a criminality that is of the law but rather as a criminality that is before the law. The Negro must be still, but must still be moving. She steals away from forced movement in stillness. (Moten, 2007, p. 228)

Projecting a curious kind of agency onto this figure, Moten concludes: "The little girl is posed as an unarticulated question. She poses a question. The posing of the question is a gift. The little girl is posed. She poses. The little girl is (ap)posed, apposes" (Moten, 2007, p. 228). While my students were sympathetic to Moten's intervention at the level of theory, it was his style - the way he describes Eakins's photograph - that soured them on the essay. Moten's prose becomes enamored with itself - its wordplay, its lyrical sensibility - and tropes on, rather than bears witness to, the figure in the picture. The disjuncture between the reproduced photograph and his description left many students feeling this was not only a critical misstep - it actively contributed to the objectification of this unnamed girl.

From that discussion on, I knew that our genealogy of Black Arts criticism had to attend not only to the big ideas in play but to the word- and sentence-level choices through which those ideas are expressed. In what follows, I use this turning point in my pedagogy to reflect more broadly on a different kind of ideological practice than that of paranoid reading. This practice tends to project meaning onto surfaces rather than dig or delve into substrata of meaning. While I affirm the social and political commitments that inform such projective reading, I suggest that, as a method, it treats the aesthetic object as an extension of the critic's ideological orientation. The resulting description of the object is often so skewed - again, simply based on perceptible qualities and features - that it would be unrecognizable to a different viewer or reader. Realizing how pervasive this aesthetic ideology was in our readings, I set aside time to discuss the role of description in interpretation and asked students to practice describing aesthetic objects with consideration and care. As I explain below, description became a means by which we could contest the dominant mode of reading in Black Studies while honing our own language and rhetoric, establishing a more ethical relation to the objects we bring under critical scrutiny.

In the debates surrounding the post-critical turn in academic discourse, it often goes assumed that we know critique when we see it: after all, a hallmark of paranoid reading is the process of bringing to light a hidden truth. Yet not all styles of critique are indebted to this model of revelation. Indeed, some styles of critique encode their ideological commitments in the way they describe the object under analysis. This point was driven home to me in the graduate seminar. As a matter of interpretation, my students and I saw how the Black Arts critical tradition generally abjures a hermeneutics of suspicion. For critics writing within this tradition, revealing the insidious operations of white supremacy is either not the point (because that is not the art they focus on) or beside the point (since revealing as much to black people would be redundant). Instead, Black Arts criticism is more concerned with making an affirmative case for the aesthetic object's resistant qualities. However, as my classroom experience showed, this aesthetic ideology, subtended by the guarantee that blackness is always resisting something, could yield disastrous results. Moten is wrong in the example I cited above not necessarily in theory but in his choice of object and the way he describes it, which is, finally, no description at all.

Another example may be taken from a critical work that draws a direct line between Black Arts art and aesthetic theory from the 1960s and 1970s and so-called post-black art and aesthetic theory from the 1990s and 2000s. Despite the vast differences in aesthetic principles, social and political meaning, and structuring conditions between these two movements, Margo Natalie Crawford's Black PostBlackness (2017) insists that they are historical mirrorimages of each other, such that Black Arts appears more deessentializing than its reputation suggests and post-black art seems more politically radical than its characterization allows. The argument, which relies on a continuous account of black aesthetic resistance, may sound good, but as one reviewer concludes, it is not supported by sustained, persuasive analysis of the numerous objects under discussion. "Often enough," Ariel Evans writes, "the descriptive and analytical brevity renders black postblackness as more adjective than argument; Crawford tells more than shows" (Evans, 2019).

If Crawford's telling makes short shrift of aesthetic objects, then her brevity perhaps does more symbolic violence than Evans is willing to state here. Take, for 
example, Crawford's examination of Glenn Ligon's Condition Report (2000), which reads:

The use of the "I Am a Man" signs, in the 1968 Memphis Sanitation workers' strike, is the collective act of black resistance that Ligon rechannels in his text painting. He adds words in the margins that identify each mark and tear on the sign. Some of these words are "Hairline crack", "Brown smudge", "Feather crack", "fingerprint", and "loss at edge". This text painting makes viewers think about the unique texture of each individual sign as opposed to the focus on the power of the collective signs in the iconic photographs of the striking sanitation workers. (Crawford, 2017, p. 100)

Crawford's description isolates itself in the echo chamber of the black post-black theory, pinging back and forth between the historical referent of the sign (the Black Arts-era strike) and Ligon's painting (the post-black moment). Yet as Evans suggests:

Nowhere does she mention that the [annotations] in Condition Report's right-hand print are the conservator's notes on damage to Ligon's 1988 painting of the Memphis sanitation workers' signs (Untitled [I Am a Man]), of which Condition Report's left print is an unannotated reproduction. (Evans, 2019)

Evans's one sentence elaboration alerts us to the fact that the work consists of two prints, that the notes had been inscribed by a conservator (which Ligon then deployed as art, to be sure), and that the comparison of prints is in many ways a meditation on Ligon's own "condition" as a black artist in the predominantly white art world (hence the side-by-side "untouched" and marred versions). None of these is germane to the historical period of 1968; they are, rather, indicative of the artist's engagement with historical memory, racialized masculinity, and the politics of museums. The work is much richer with Evans's description, and it is so in spite of Crawford's theory.

Black Studies is far from the only field to use selective, incomplete, or even misleading description to advance ideological commitments. As a technique of projective reading, inadequate description has taken hold across the humanities as just another way of making the aesthetic object do the theoretical or critical work one already wants it to do. The hermeneutics of suspicion has been accused of similarly reductive analysis. However, psychoanalytic and Marxist modes of interpretation are rarely thought to be lacking in descriptive capacity. If anything, paranoid reading relishes description precisely because hints of repressed energy or suppressed exploitation are contained in the smallest bits of evidence, textual or otherwise. In this way, paranoid readers are the uncanny kin to strict formalists in their veneration of close reading. Where they diverge is in the upshot, or consequences, of what they are able to limn in their close readings.

By contrast, as we have seen with Moten and Crawford, projective reading advances its critique on the surface of the text, whether it be a photograph, a work of visual art, a poem, or a performance. This superficial mode of interpretation has proven especially attractive to identity-based modes of critique that, rather than take an oppositional approach to reading (e.g., going “against the grain” of the text), enforce a self-identity between the critic and her object. Though perhaps well-intentioned, this style entails its own kind of symbolic violence insofar as anything not self-identical in the object is minimized, glossed over, or not described at all. This can be seen in Moten's adducing resistance in the naked girl's pose and in Crawford's assigning agency to Ligon by way of the annotations. Here the guarantee of inadequate description is that the social and political desires of an identity group (resistance, agency) will be reflected in a selected object. Once that guarantee is in place, anything in the aesthetic object that resists the critic's projections will simply be ignored or explained away.

By now it should be clear that I consider inadequate description not just misguided but unethical. It is unethical because it has a tendency of speak for aesthetic objects, to impute meaning on them that they cannot bear. To be clear, this is not to deny the validity of the social and political commitments that inform projective reading. These are commitments worth fighting for, whether in social and political life writ large or in an academy that stands to benefit from admitting more underrepresented minorities into its faculty ranks. That said, I do think these commitments are done a disservice when tied to a mode of interpretation that has an audience of one: the critic. When art and aesthetic theory are instrumentalized to affirm an ideology of inherent resistance, we sunder the ethics of interpretation, which involves the recognition that the aesthetic object exists outside ourselves. This minimal difference between critic and object ought to be observed, and that is what I aimed to do by creating an exercise around observation and description in my graduate seminar.

In her essay "The Power of Patience", art historian Jennifer L. Roberts shares how she has tried to slow down the tempo of the undergraduate and graduate learning experience, "creating opportunities for students to engage in deceleration, patience, and immersive attention” (Roberts, 2013). Her rationale for doing so is persuasive: outside of the 
classroom, social and technological pressures are "pushing students in the other direction, toward immediacy, rapidity, and spontaneity" (Roberts, 2013). So much of teaching feels like it needs to keep up with this relentless pace of change and connection, outreach and relevance. As a result, the classroom risks becoming an extension of the sped-up flows and rhythms of social media, news consumption, and other modes of largely unreflective engagement. Roberts thus proposes the value of slowing down to a twenty-first century humanistic pedagogy quite aware of the media environment around it.

The exercise Roberts shares as an example of this pedagogy is tied to a conventional assignment: "write an intensive research paper based on a single work of art" of the student's choosing at a local museum. But before the student conducts any research, she "would first be expected to go to the [museum] where it hangs, and spend three full hours looking at the painting, noting down...her evolving observations as well as the questions and speculations that arise from those observations" (Roberts, 2013). The exercise's far-reaching potential lies in its seemingly excessive duration. Because students are not used to sitting for even three minutes attending to a single object, they initially resist the terms of the exercise: "How can there possibly be three hours' worth of incident and information on this small surface? How can there possibly be three hours' worth of things to see and think about in a single work of art?" (Roberts, 2013). Yet once they give themselves over to the exercise, the results, according to Roberts, have been extraordinary. Attending to the work for that length of time in a contemplative milieu does yield a completely different level of insight. Students learn, from patient examination and reexamination (as much of their own interpretations as the work itself), "that in any work of art there are details and orders and relationships that take time to perceive" (Roberts, 2013).

Roberts's pedagogy shares projective reading's commitment to interpreting surfaces. In some respects, both assume that the perceptible world contains depths of meaning that have yet to be fully reckoned with. Unlike projective reading, however, durational attention abides an ethics of interpretation where the critic gives herself over to experiencing the aesthetic object on its own terms. By that, I simply mean that the object's being-in-the-world can never be self-identical to the critic's, and that observing this minimal difference affords the deepest kind of aesthetic pleasure and critical insight. The parameters of Roberts's exercise allow students to enter into this dynamic relation. It asks them to step outside their received habits of mind by immersing themselves in the process of contemplation. In so doing, students' readings of a single work inevitably change and become layered over the three-hour span. New details emerge, different connections reveal themselves, interpretations are nuanced and enhanced. By helping students see how their own impressions can change over time, the exercise makes the powerful intellectual point that “just because you have looked at something doesn't mean that you have seen it. Just because something is available instantly to vision does not mean that it is available instantly to consciousness" (Roberts, 2013).

Roberts's exercise struck me as the perfect model for creating new habits of mind that would help my students become better observers and critics of black art. Using "The Power of Patience" as a guide, I devised a non-graded assignment in conjunction with my seminar's field trip to see the 30 Americans exhibition of contemporary works by black artists at the Barnes Foundation in Philadelphia. The assignment asked them to sit with one object for at least 30 minutes, to note their initial and changing observations about the object, and, finally, after the visit, to write a description of the object based on their notes. The shortened duration was less-than-ideal, but it was the most I could do given our limited time at the museum. And unlike Roberts's overall assignment, which asks for a standard art-historical research paper, my goal was to channel students' observations into a single act of ekphrasis: describe the object in front of you.

The exercise proved deeply rewarding in the moment. Students remained in the small exhibition space for the entire hour and a half of our visit. And though it took some a while to settle in front of an object, all gave the exercise a try and noted their observations accordingly. I asked not for intense concentration nor for an exacting eye; this was not about getting the details "right." Instead, I asked my students to give themselves over to another's intention, an artist's effort to create a work that does something in the world, both in the physical space of the museum but also in the mind space of contemplation. After trying their hand at durational attention, my students and I wandered through the rest of the exhibition with newly opened eyes, eager to engage with each other about works we had seen, had yet to see, or simply could take in together. It was one of the most pleasant collective experiences of museum-going I had ever had.

The following week, when it came time to share our examples of ekphrasis, I was struck by the absence of ideological rhetoric in the descriptions of what my students saw. Though all of the works were by black artists, race or the perception thereof did not dictate their descriptions. Instead, the students lingered over the works' details in all their specificity. Colors, shapes, and forms were intricately described; representations of a figure, subject, or scene were teased out as aesthetic renderings, even when they 
approached verisimilitude; and the works themselves were situated in the space of the exhibition, such that a certain logic behind their curation could be gleaned from the surround of contemplation. Mind you, I am not a trained art historian, and I did not presume to teach art-historical methods to my students. Where someone did not know the technical term for something, the advice was always to use as basic a description as possible to convey the effect. But it worked. The descriptions my students wrote were more compelling than those we encountered in projective reading. They also were more honest to students' actual encounters with art, which defied rote prescriptions, easy assumptions, and even initial impressions. It was unusual to hear scholars-intraining talk about the process of changing their minds the longer they sat with a work, yet that is exactly what durational attention brought to their writing. In making space for that small degree of uncertainty, students actually came across more assured in their writing and more astute in their critical observations. Though their work was limited to observation and description, my students' embrace of the parameters of the exercise meant that genuine theoretical analysis was embedded in their critical practice.

The semester concluded with a reading of Wayward Lives, Beautiful Experiments. The book had just been published to rave reviews and has since become a modern classic of Black Studies, feminist theory, and an interdisciplinary field conceived as archival poetics. The book resists easy categorization insofar as it aims to recover the undocumented stories of black girls and women who flocked to Northern cities at the turn of the twentieth century to create new lives for themselves. Because these stories are undocumented, Hartman employs a method of critical fabulation to speculate about these girls' and women's interior lives - their hopes and dreams, desires and disappointments - in the face of scant historical evidence of the same (Hartman, 2008). It is a Black Arts-descended project to the extent that Hartman construes the lostness of her historical subjects as an opportunity to fictionalize their intimate lives and everyday observations. Though lacking the empirical grounding of historiography, Wayward Lives has been praised by numerous practitioners of identity-based modes of critique as a way of recovering the subjectivities of those never granted full, complex humanity under racist, sexist, capitalist, and homophobic regimes of power.

To my surprise, since I had not known this when I assigned Wayward Lives, Eakins's photograph of the nude black girl is the key object of analysis at the beginning of the book. At first, Hartman provides a description that limns the photograph as photograph:
The rigidness of the body betrays the salacious reclining posture, and the girl's flat steely-eyed glare is hardly an invitation to look. She retreats as far away from the camera as possible into the corner of the sofa, as if seeking a place in which to hide. (Hartman, 2019, p. 25)

Yet after this description, Hartman's commitment to fabulation leads her to turn inward, to become enamored with her own take on this disturbing image. "Was it possible to annotate the image?", she asks, "To make my words into a shield that might protect her, a barricade to deflect the gaze and cloak what had been exposed?" And further: "So much time accumulates on her small figure, the girl might well be centuries old, bearing the weight of slavery and empire, embodying the transit of the commodity, suturing the identity of the slave and the prostitute." And then: "How does the pleasure taken in the image of sexual assault issue from the girl's invitation? It is a picture redolent with the auction block, the plantation, and the brothel” (Hartman, 2019, pp. 26-27). These associative claims, which are far removed from the actual photograph Hartman describes, seem to abjure the usual resistance rhetoric one finds in projective reading. That is not the effect, however, insofar as Hartman literally projects the Eakins photograph onto the facing pages on which these quotations are printed. The image is blown up at full bleed, covering the entire plane, with the binding bisecting the figure's torso. "Annotating" the photograph is thus not a rhetorical question - it is the very thing Hartman does to "protect" this subject from our gaze. Yet by inserting herself so crudely into the analysis, Hartman redoubles the gaze's power: we peer more closely at the blurred figure, wondering why she is splayed across the book in front of us. Reproducing the image rather than relying on ekphrasis continues to make this girl's body available for public circulation and consumption. It is unethical.

Subsequent pages offer the interpretive upshot of Hartman's literalization of projective reading. A detail of the photograph, showing the girl's face and bare chest, appears on the next page and is supposed to recover something of the girl's humanity. Here resistance and agency are projected onto the image in ways that are just as problematic as Moten's earlier essay. "Looking at the photograph, one can discern the symphony of anger residing in the arrested figure," Hartman writes, resorting to the cliché of sound as a touchstone of black resistance to white supremacy. As for the self-identity of the critic and her object, Hartman is candid:

The entanglement of violence and sexuality, care and exploitation continues to define the meaning of being black and female. At the same time, I had to move beyond the photograph and find another path to her. How might 
this still life yield a latent image capable of articulating another kind of existence, a runaway image that conveys the riot inside? (Hartman, 2019, pp. 29-30)

Why, one might ask of Hartman, is it this photograph's burden to bear the critic's need to find escape from inhospitable circumstances? Are we not blinding ourselves to the actual conditions of exploitation that led to this image being taken by attributing resistance and agency to the girl's figure? Indeed, it would seem more plausible to conclude that Eakins exploited an actual runaway to create this photograph. Why valorize a quality that the pornographic image itself seems to relish?

And yet. Back in the classroom, the layout and Hartman's exercise in fabulation did not disturb my students as much as it did me. The reading worked, some of them argued, because it balanced a better description of the photograph with a similar theoretical insight to Moten's. On this count, I did not disagree with them, and I left it at that in our discussion. The seminar ended the following week, and my students turned in superb final research papers that deployed nuanced descriptions of music, film and video, public art, and literary texts. They might have granted Hartman the benefit of the doubt, but none was about to emulate her style.
As I look back on teaching Wayward Lives, and as I reflect on how Eakins's photograph constituted the true bookends of our seminar, I am reminded of the lure of projective reading to identity-based modes of critique. Hartman and Moten end up in the same place with regard to the photograph. But whereas Moten's style highlights his own voice as an interpreter of the image, I now see that Hartman's style deploys the ultimate strategy of projection: it speaks for the psychology of another. The rhetorical flourishes, the wonderings and wanderings, the incessant use of free indirect discourse: critical fabulation conceals its ideological commitments by writing as if they emerge out of the deepest recesses of another's psyche. This mode of projective reading does not practice the hermeneutics of suspicion so much as marshal that hermeneutics' depth metaphors to its advantage. As such, the near-universal celebration of so-called lyricism in academic prose is a troubling sign of the psychologization of the ideology of aesthetic resistance at the level of style. Against this trend, I offer my trial run of a pedagogy of description - patient in observation, prosaic in development, ethical in orientation as one way of cutting through such obfuscation.

\section{References}

Baraka, A. (1963). Blues people. Negro music in white America. William Morrow \& company.

Crawford, M. N. (2017). Black post-blackness: The black arts movement and twenty-first-century aesthetics. University of Illinois Press.

Evans, A. (2019, November 26). [Review of the book Black post-blackness: The black arts movement and twenty-first-century aesthetics, by M. N. Crawford]. CAA Reviews. http://caareviews.org/reviews/3592\#.X1A5OtNKj_Q

Hartman, S. (2008). Venus in two acts. Small Axe, 12(2), 1-14.

Hartman, S. (2019). Wayward lives, beautiful experiments: Intimate histories of social upheaval. Norton.

Moten, F. (2007). Taste dissonance flavor escape: Preface for a solo by Miles Davis. Women and Performance, 17(2), 217-246.

Roberts, J. L. (2013, November-December). The power of patience. Harvard Magazine. https://harvardmagazine.com/2013/11/the-power-of-patience

\section{Recommended Citation}

Nishikawa, K. (2020). Pedagogy of description. Projective reading and the ethics of interpretation. On Education. Journal for Research and Debate, 3(9). https://doi.org/10.17899/on_ed.2020.9.4

About the Author

Kinohi Nishikawa is Associate Professor of English and African American Studies at Princeton University. His book Street Players: Black Pulp Fiction and the Making of a Literary Underground was published by the University of Chicago Press in 2018. He has 
written on African American literary history and print and popular culture for the journals American Literary History, Chicago Review, PMLA, and MELUS, as well as the essay collections Post-Soul Satire, The Blacker the Ink, Against a Sharp White Background, and Black Cultural Production after Civil Rights. Nishikawa's new book project, Black Paratext, is a history of modern African American literature and book design. 